\title{
A Case of Second Branchial Cleft Sinus with Double Opening from the Tonsil
}

\author{
Do Hoon $\mathrm{Kim}^{1}$ and Dong Kun Lee ${ }^{2}$ \\ ${ }^{1}$ Department of Otolaryngology-Head and Neck Surgery, Busan Paik Hospital, Inje University College of Medicine, Busan; and \\ ${ }^{2}$ Department of Otolaryngology-Head and Neck Surgery, Dong-A University College of Medicine, Busan, Korea
}

\section{편도 개구부가 2 개인 제 2 새열동 1 예}

\author{
김 도 훈 $^{1}$ 이 동 근 $^{2}$ \\ 인제대학교 의과대학 부산백병원 이비인후-두경부외과학교실, ${ }^{1}$ 동아대학교 의과대학 이비인후-두경부외과학교실 ${ }^{2}$
}

\author{
Received November 12, 2016 \\ Revised December 11, 2016 \\ Accepted December 17, 2016 \\ Address for correspondence \\ Dong Kun Lee, MD, PhD \\ Department of Otolaryngology- \\ Head and Neck Surgery, \\ Dong-A University \\ College of Medicine, \\ 26 Daesingongwon-ro, Seo-gu, \\ Busan 49201, Korea \\ Tel +82-51-240-5428 \\ Fax +82-51-253-0712 \\ E-mail chaos001@hanmail.net
}

Second branchial cleft anomaly is the most common type of branchial anomalies. Tonsillitis can cause inflammation or infection through the cleft tract. We present an extremely rare case of a 15 -year-old female with a tonsil sinus that caused a deep neck infection of the neck, showing a double-sinus opening. The patient was successfully treated with trichloroacetic acid chemocauterization.

Korean J Otorhinolaryngol-Head Neck Surg 2018;61(5):263-6

Key Words Abscess $\cdot$ Branchial cleft anomalies $\cdot$ Fistula $\cdot$ Neck $\cdot$ Sinus.

\section{서 론}

새열기형(branchial anomalies)은 소아 경부 종물의 약 $17 \%$ 를 차지하며 새열기형은 태생 4에서 8주 사이에 불완전한 새 열(branchial cleft)의 폐쇄로 발생한다. ${ }^{1,2)}$ 종류는 기원에 따라 제 1 , 제 2 , 제 3 , 그리고 제 4 형들이 있는데, 그중 2형 새낭(branchial cyst)의 폐쇄가 되지 않아 발생하는 제2 새열기형이 약 90\%이며 새열동이나 새열루에서는 내부 개구부가 편도 하부 에서 발생한다. ${ }^{3)}$ 새열동은 경부 종물로 나타날 수도 있고 누 공을 통한 편도의 염증이나 인두 분비물에 의한 오염은 심경 부감염을 유발하며, 재발의 원인이 되기도 한다. 저자들은 심 경부감염이 동반된 제 2 새열동에서 2 개의 편도 개구부가 있는 극히 드문 사례를 발견하였고, 화학소작술로 성공적으로 치

This is an Open Access article distributed under the terms of the Creative Commons Attribution Non-Commercial License (http://creativecommons.org/licenses/by-nc/4.0) which permits unrestricted non-commercial use, distribution, and reproduction in any medium, provided the original work is properly cited.
료하여 문헌 고찰과 함께 보고하는 바이다.

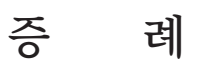

15세 여자로 급성간염으로 내과 입원 중 인후통, 발열, 전신 근육통을 호소하였다. 이학적 검사상 $38.2^{\circ} \mathrm{C}$ 였고, 양측 편도 에 발적과 노란 삼출물이 동반된 편도염 소견이었다. 경구 항 생제 투여 1 주 후 편도염은 호전되었으나 좌측 경부 부종이 발생하였고, 2주째 경부 부종과 통증이 악화되었다. 경부컴 퓨터단층촬영 소견상 불분명한 조영 증강을 보이는 큰 농양 이 좌측 악하선의 후방과 내측에서 흥쇄유돌근의 내측을 따 라 쇄골 위까지 관찰되었다(Fig. 1A). 편도에 농양은 없었으 며, 설골 아래 높이에서 경부의 농양이 인두와 이어지는 소견 이 보였다(Fig. 1B). 이학적 소견 체온은 $37.2^{\circ} \mathrm{C}$, erythro-cyte sedimentation rate $84 \mathrm{~mm} / \mathrm{hr}, \mathrm{C}-$ reactive protein(quantitive) $14.7 \mathrm{mg} / \mathrm{dL}$ 로 상승된 소견 이외에는 특이소견은 없었 
다. 심경부 농양이 병발한 제2 새열동의 소견으로 입원하여 항생제 치료, 절개 배농 수술 그리고 인후두 개구부를 찾기 위해 전신마취하에서 후두 미세 수술법을 이용한 인후두 평 가를 계획하였다.

현미경하에서 설기저부, 편도, 인두, 후두, 이상와에서 누공 을 찾아보았지만, 발견되지 않았다. 절개 배농은 쇄골 상부 두 손가락 높이에서 평행하게 $2 \mathrm{~cm}$ 피부를 절개하여 성공적 으로 배농하고 생리식염수로 세척한 후 배농관을 넣었다. 이후
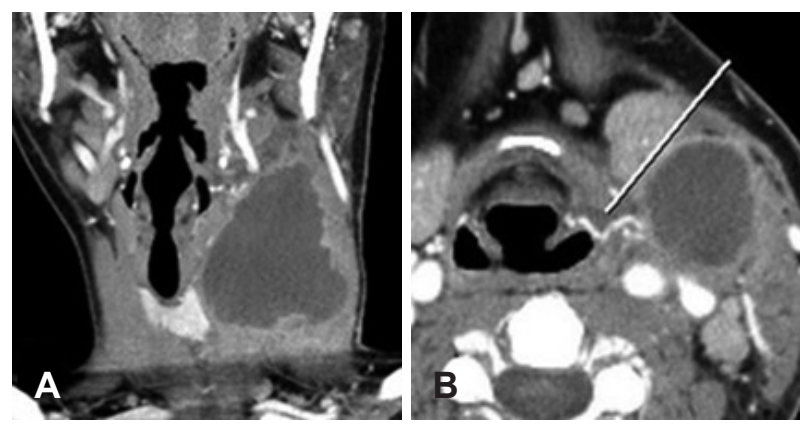

Fig. 1. Contrast enhanced computed tomographic scan of 15-yearold female. A large infected branchial cleft sinus is showing at left neck with irregular rim enhancement (A). A cervical abscess is extending from the pharyngeal tract under the hyoid level (white line) (B).

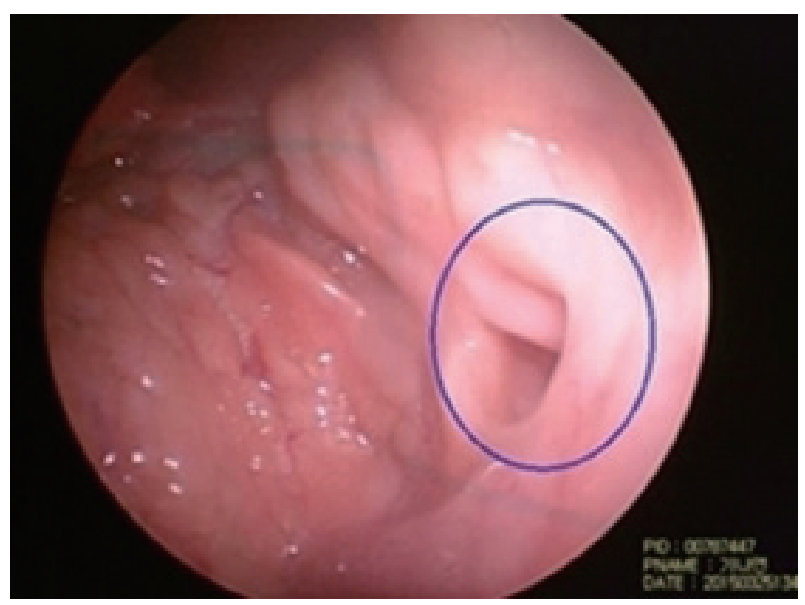

Fig. 2. Endoscopic image is showing sinus opening from the tonsil (circle). The other sinus opening is not showing yet.
배농관을 통해 세척과 정맥 내 항생제 치료를 시행하였다. 균 배양 결과는 Streptococcus viridans 가 다수 배양되고, cephalosporin계를 포함한 대부분 항생제에 감수성이 있었다. 수 술 후 6일째 통증과 부종, 혈액 수치가 상당히 호전되었고, 누 공을 찾기 위해 식도조영술을 시행하였지만 누공은 발견되지 않았다. 경구 항생제를 투여하고 환자는 퇴원하였다.

수술 후 11 일째 외래 검진에서 경부의 부종과 통증은 모두 호전되었다. 구강 내시경 검사에서 좌측 편도 중간 부위에 동 개구부(sinus opening)가 발견되었다(Fig. 2). 새열낭의 수술 적 완전 적출술과 개구부의 화학소작술 두 가지 치료법을 환 자와 보호자에게 설명하였고, 미용적인 이유로 개구부 화학 소작술을 시행하기로 하였다. 전신마취하에 McIvor mouth $\mathrm{gag}$ 로 혀를 견인하여 시야를 확보하고 현미경하 검사를 시행 하였는데 좌측 편도 중간 부위에 2개의 개구부가 발견되었다 (Fig. $3 \mathrm{~A}$ ). 각각의 개구부에는 황색의 염증성 삼출물과 이물 질이 차있었고 개구부를 따라 $2 \mathrm{~mm}$ 직경의 흡인관을 삽입하 였을 때 $1 \mathrm{~cm}$ 이상 들어갔으며, $3 \times 1 \mathrm{~cm}$ 의 솜거즈(cottonoid patties)를 누공에 삽입하였을 때 충분히 들어가고도 공간이 남았다(Fig. 3). 위의 새열동의 개구부가 편도움(tonsillar crypt) 이 아닌 것을 확인하기 위해 편도 각각의 개구부 안쪽 점막의 조직검사를 시행하였다. $40 \%$ 트리클로로아세트산(trichloroacetic acid)을 솜거즈에 적신후 개구부 안쪽의 누공 벽과

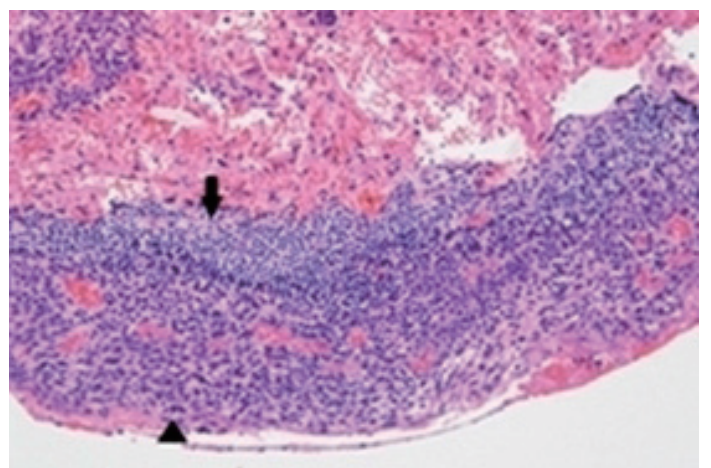

Fig. 4. Histopathology of the specimen shows squamous epithelium-lined cyst wall (arrowhead) with subepithelial lymphocytes infiltration (arrow, H\&E, $\times 200$ ).
Fig. 3. Intraoperative microscopic findings. Upper sinus opening is proved with $2 \mathrm{~mm}$ suction tip (arrowhead). The other opening is collapsed (arrow) (A). For chemocauterization, $3 \times 1 \mathrm{~cm}$ trichloroacetic acid soaked cottonoid patties are inserted at each sinus openings. Dotted circles indicate each upper (arrowhead) and lower (arrow) sinus openings (B).
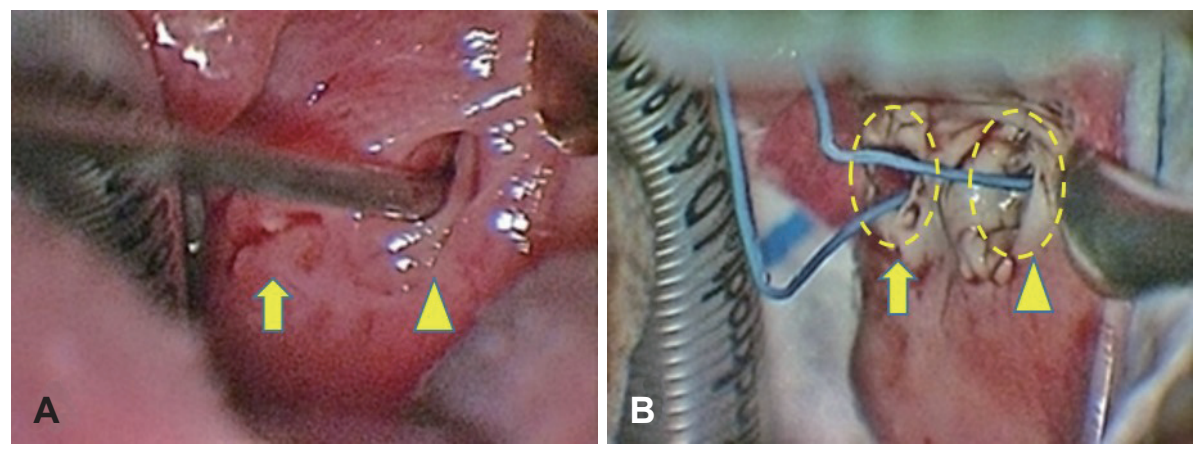
개구부 점막을 소작한 후, 식염수 거즈로 닦아내기를 4회 반 복하였다. 환자는 당일 저녁에 특별한 합병증 없이 퇴원하였 다. 개구부 조직의 병리검사 결과 누관의 벽은 중층 편평상피 로 구성되어 있고 염증세포의 침윤이 동반되어 있었다. 따라 서 2 개의 개구부를 가진 제2형 새열동으로 진단되었다(Fig. 4). 3 주 후 환자가 외래 방문했을 때 증상은 호전되었고 술 후 11 개월까지 재발이나 합병증은 없었다.

\section{고 찰}

저자들은 편도염 이후 농양이 합병된 제2 새열동을 치료하 면서 편도 개구부가 두개인 극히 드문 사례를 경험하였다. 새 열기형의 누공은 단일 누공으로 일반적으로 알려져 있는데, 복수의 누공을 가진 새열기형은 지금까지 국내에서는 보고 된 바가 없으며, 전 세계적으로는 단 2예가 보고되었다. 32세 남자의 CT에서 이중 낭관(double cyst tract)을 보이는 제2새 열낭 1 예로 스페인 증례 보고가 있으며, ${ }^{4}$ 13세 여아에서 이 중 이상와 누공이 갑상선과 연결된 1 예가 일본에서 보고되었 다. ${ }^{5)}$ 본 증례는 경부컴퓨터단층촬영에서 경부 농양이 인두로 부터 이어져 내려오는 소견과 편도에서 명확히 분리된 두 개 의 개구부가 육안으로 관찰되고 흡인기나 솜거즈가 $1 \mathrm{~cm}$ 이 상 깊이 충분히 들어가는 소견 그리고 각각의 개구부 조직 검 사에서 염증성 삼출물과 누관벽을 이루고 있는 편평상피조 직이 발견된 소견으로 편도 개구부가 2 개인 제 2 새혈동으로 진단되었다. 개구부 조직학적 검사에서 심한 염증과 이물질 을 동반한 상피조직의 나열 소견은 새열기형의 다른 병리 보고 와 같은 소견이었고, 이물질의 존재 또한 구강이나 인두 공간 으로의 연결이 있기 때문에 발생하는 것으로 알려져 있다.5)

새열기형의 치료는 완전 적출이 원칙이지만 이전에 수술을 받거나, 염증이 있었던 경우에는 누관을 찾아서 완전하게 적 출하는 것이 쉽지 않다. 다른 치료법으로 새열기형의 이상와 누공을 트리클로로아세트산을 사용한 화학소작술로 성공적 으로 치료한 보고가 있다. ${ }^{6-8)} \mathrm{Hwang}$ 등 ${ }^{8)}$ 은 완전 적출술과 비 교하였을 때 치료 결과에서 유의한 차이가 없었다고 보고하 였다. 화확소작술의 치료 성공률은 75 91\%로 보고되고 있 다. ${ }^{9-11)}$ 위 치료의 장점은 완전 절제가 어려운 경우에 유용하 며, 광범위한 피부 절개가 필요 없으며, 급성 염증이 있을 경 우에도 동시에 시행할 수 있고, 재발한 경우에 수술적 완전 절제가 가능하며, 짧은 마취시간과 짧은 입원기간, 그리고 심 각한 합병증이 없어서 보전적인 치료를 생각할 수 있는 환자 에서 적용될 수 있다.,12) 본 증례와 같이 새열기형이 비교적 젊 은 환자들에게 발생하기 때문에 절개 수술법에 비해 미용적 인 장점이 있다. 단점은 편도의 경우는 수술적 접근이 쉽지만,
이상와의 경우는 후두경을 삽입할 수 있을 정도의 구강 벌어 짐이나 경추의 안정성이 필요하며, 개구부를 확실히 폐쇄하 기 위해서는 반복적인 시술이 필요할 수 있다. ${ }^{8)}$ 더구나 남아 있는 상피조직이 장기적으로 어떤 영향이 있을지 아직 연구가 부족하다.

반복되는 감염이 발생하는 경부 농양의 경우 인두나 후두로 이어지는 누공을 가진 새열낭종을 의심해야 한다. 누공의 위 치를 찾기 위해 컴퓨터단층촬영, 바륨 식도조영술, 후두내시 경, 초음파, 자기공명영상 등이 이용되고 있지만, 발견하기가 어렵다. 식도조영술이나 후두내시경이 그중 유용한 검사이며, 급성 염증이 있을 때에는 부종으로 인해 누공이 일시적으로 닫히거나 안보일 수 있기 때문에 염증을 치료한 후에 다시 정 밀하게 평가할 필요가 있다. 본 사례에서도 경부 농양 수술 후 호전이 보여 7일째 식도조영술을 하였으나, 개구부는 보이지 않았다. 보고에 따르면 바륨 식도조영술의 이상와 누공 진단 의 민감도는 28.6 100\%로 다양한데, 이는 검사 시 환자의 협 조가 부족하거나 개구부의 일시적 폐쇄로 인한 것으로 추정 된다. ${ }^{8,13,14)}$ 후두내시경의 경우에는 $95.2 \%$ 의 높은 누공 진단 민감도를 보였다. ${ }^{8}$ 한 가지 검사에 의존하지 말고 여러 가지 검 사의 방법을 이용해야 하며, 무엇보다 임상적인 의심을 하고 주의 깊게 살펴보는 것이 필수적이다. 본 증례처럼 인두나 후 두의 개구부 화학소작술을 시행할 경우에는 드물긴 하지만 새열기형의 개구부가 1 개 이상일 가능성도 염두하고 세심히 치료해야 재발을 예방할 수 있다.

이중 누공에 관한 보고는 아직 2개의 사례밖에 없고, 발생 기전이나 빈도에 대해 알려진 바가 없다. 제 3,4 새궁기형이 결 합되어 나타난 보고가 한 개 있다. ${ }^{15)}$ 새열기형이 단순한 형태 만 있는 것이 아니라, 이중 새열 누공이나 복합 새궁기형 등의 다양한 형태를 보일 수 있음을 제시한 것이 이 사례 보고의 가 치라고 생각하며, 향후 더 많은 연구가 필요하겠다.

\section{REFERENCES}

1) Doi O, Hutson JM, Myers NA, McKelvie PA. Branchial remnants: a review of 58 cases. J Pediatr Surg 1988;23(9):789-92.

2) Joice P, Sudarshan T, Hussain SS. First branchial arch abnormality: diagnostic dilemma and excision with facial nerve preservation. J Laryngol Otol 2012;126(9):918-22.

3) Park YH, Lee JH, Kim JH, Cho SH. Bilateral second branchial cleft fistulas: a case report. Korean J Otolaryngol-Head Neck Surg 2005;48(5):676-9.

4) Muñoz-Fernández N, Mallea-Cañizares I, Fernández-Julián E, De La Fuente-Arjona L, Marco-Algarra J. [Double second branchial cleft anomaly]. Acta Otorrinolaringol Esp 2011;62(1):68-70.

5) Shino M, Yasuoka Y, Nakajima K, Chikamatsu K. A case of pyriform sinus fistula infection with double tracts. Case Rep Otolaryngol 2014;2014:126840.

6) Pereira KD, Smith SL. Endoscopic chemical cautery of piriform sinus tracts: a safe new technique. Int J Pediatr Otorhinolaryngol 2008;72(2):185-8. 
7) Miyauchi A, Inoue H, Tomoda C, Amino N. Evaluation of chemocauterization treatment for obliteration of pyriform sinus fistula as a route of infection causing acute suppurative thyroiditis. Thyroid 2009;19(7):789-93.

8) Hwang J, Kim SC, Kim DY, Namgoong JM, Nam SY, Roh JL. Excision versus trichloroacetic acid (TCA) chemocauterization for branchial sinus of the pyriform fossa. J Pediatr Surg 2015;50(11):194953.

9) Cha W, Cho SW, Hah JH, Kwon TK, Sung MW, Kim KH. Chemocauterization of the internal opening with trichloroacetic acid as first-line treatment for pyriform sinus fistula. Head Neck 2013; 35(3):431-5.

10) Sun JY, Berg EE, McClay JE. Endoscopic cauterization of congenital pyriform fossa sinus tracts: an 18-year experience. JAMA Otolaryngol Head Neck Surg 2014;140(2):112-7.
11) Miyauchi A, Matsuzuka F, Kuma K, Takai S. Piriform sinus fistula: an underlying abnormality common in patients with acute suppurative thyroiditis. World J Surg 1990;14(3):400-5.

12) Kim KH, Sung MW, Lee KJ, Roh JL, Kwon TK, Kim IS, et al. Management of Pyriform Sinus Fistula with Chemocauterization. Korean J Otolaryngol-Head Neck Surg 2002;45(9):906-10.

13) Park SW, Han MH, Sung MH, Kim IO, Kim KH, Chang KH, et al. Neck infection associated with pyriform sinus fistula: imaging findings. AJNR Am J Neuroradiol 2000;21(5):817-22.

14) Sheng Q, Lv Z, Xiao X, Zheng S, Huang Y, Huang X, et al. Diagnosis and management of pyriform sinus fistula: experience in 48 cases. J Pediatr Surg 2014;49(3):455-9.

15) Mehrzad H, Georgalas C, Huins C, Tolley NS. A combined third and fourth branchial arch anomaly: clinical and embryological implications. Eur Arch Otorhinolaryngol 2007;264(8):913-6. 